\title{
23. LOW-MOLECULAR-WEIGHT HYDROCARBONS IN SEDIMENTS OF DEEP SEA DRILLING PROJECT LEG 89, SITES 585, EAST MARIANA BASIN, AND 586, ONTONG-JAVA PLATEAU1
}

\author{
Rainer G. Schaefer and Detlev Leythaeuser, Institut für Erdöl und Organische Geochemie, Jülich, \\ Federal Republic of Germany²
}

\begin{abstract}
$\mathrm{C}_{2}-\mathrm{C}_{8}$ hydrocarbon concentrations (about 35 compounds identified, including saturated, aromatic, and olefinic compounds) from 38 shipboard sealed, deep-frozen core samples of Deep Sea Drilling Project Sites 585 (East Mariana Basin) and 586 (Ontong-Java Plateau) were determined by a gas stripping-thermovaporization method. Total concentrations, which represent the hydrocarbons dissolved in the pore water and adsorbed on the mineral surfaces of the sediment, vary from 20 to $630 \mathrm{ng} / \mathrm{g}$ of rock at Site 585 (sub-bottom depth range 332-868 m). Likewise, organic-carbon normalized yields range from $3 \times 10^{4}$ to $9 \times 10^{5} \mathrm{ng} / \mathrm{g} \mathrm{C}_{\mathrm{org}}$, indicating that the organic matter is still in the initial, diagenetic evolutionary stage. The highest value (based on both rock weight and organic carbon) is measured in an extremely organic-carbon-poor sample of Lithologic Subunit VB (Core 585-30). In this unit (504-550 m) several samples with elevated organic-carbon contents and favorable kerogen quality including two thin "black-shale" layers deposited at the Cenomanian/Turonian boundary (not sampled for this study) were encountered. We conclude from a detailed comparison of light hydrocarbon compositions that the Core 585-30 sample is enriched in hydrocarbons of the $\mathrm{C}_{2}-\mathrm{C}_{8}$ molecular range, particularly in gas compounds, which probably migrated from nearby black-shale source layers.

$\mathrm{C}_{2}-\mathrm{C}_{8}$ hydrocarbon yields in Site 586 samples (sub-bottom depth range 27-298 m) did not exceed $118 \mathrm{ng} / \mathrm{g}$ of dry sediment weight (average $56 \mathrm{ng} / \mathrm{g}$ ), indicating the immaturity of these samples.
\end{abstract}

\section{INTRODUCTION}

In the East Mariana Basin at Site 585 of Deep Sea Drilling Project (DSDP) Leg 89, drilling was undertaken in October-November 1982 by the Glomar Challenger. The main objective at this site was to search for sedimentary sections that would reveal paleoceanographic conditions in the Mesozoic "super-ocean," the ancestor of today's western Pacific. Originally planned as a reentry hole, Site 585 was drilled as two single-bit holes to 763 and $893 \mathrm{~m}$ sub-bottom depth, respectively. Thus the original scientific objective of this cruise, that is, to drill into the oldest, Jurassic remnants of the seafloor in the Pacific, was not achieved. The lowermost part of the drilled section consists of $300 \mathrm{~m}$ of upper Aptian to middle Albian hyaloclastite-rich volcanogenic sediments of turbidites and debris flows. Above this coarse volcanogenic section lies a generally finer-grained section of radiolarian- and zeolite-rich siltstones, claystones, and nannofossil chalks that were also redeposited by turbidity currents and/or debris flows. The bulk of the sediments penetrated consists of very organic-carbon-poor sediments. Organic-carbon-rich sediments occurred only as two thin bands very close to the Cenomanian/Turonian boundary in both holes.

This chapter examines the conditions for generation and migration of the low-molecular-weight hydrocarbons as determined in 29 core samples from Site 585 (19 from Hole 585 and 10 from Hole $585 \mathrm{~A}$ ).

As shown in previous studies (e.g., see Whelan and Hunt, 1981, 1982; Schaefer et al., 1983a, b; Schaefer

\footnotetext{
${ }^{1}$ Moberly, R., Schlanger, S. O., et al., Init. Repts. DSDP, 89: Washington (U.S. Govt. Printing Office).

2 Address: Institut für Erdöl und Organische Geochemie, KFA Jülich GmbH, Postfach 1913, D-5170 Jülich, Federal Republic of Germany.
}

and Leythaeuser, 1984; Schaefer et al., 1984, and references cited therein), quantity and composition of hydrocarbons of this molecular-weight range represent a sensitive indicator for the thermally controlled hydrocarbon generation reactions in low-maturity sediments.

Finally, nine hydraulic-piston-cored samples of DSDP Site 586 (Ontong-Java Plateau), mainly consisting of very organic-carbon-poor Neogene nannofossil oozes and chalks, were analyzed in the same way.

All samples for this study were stored in sealed vials and deep-frozen on board. Contamination by acetone, which is usually applied in large quantities during corecutting procedures on board Glomar Challenger (cf., Schaefer et al., 1983b), was minimized.

\section{METHODS}

Thirty-eight sediment samples (approximately $10 \mathrm{~g}$ ) were obtained on board immediately after the cores had been cut into sections. This was necessary in order to minimize the contamination of the cores by acetone. Samples were stored in aluminum-foil-sealed, 20-ml, screwcapped glass flasks in deep freeze (approximately $-20^{\circ} \mathrm{C}$ ) until the analyses were performed in the laboratory at KFA Jülich. Blank runs revealed an adequate purity of the sampling vials used for this study. The low-molecular-weight hydrocarbons (molecular range $\mathrm{C}_{2}-\mathrm{C}_{8}$ ) were determined by a slightly modified, combined gas-stripping-thermovaporization method (Schaefer et al., 1978) described in detail in our previous studies of DSDP Legs 71, 75, and 79 sediments (Schaefer et al., 1983a, b; Schaefer and Leythaeuser, 1984; Schaefer et al., 1984). The relative standard deviation of hydrocarbon stripping yields was determined to be around $10 \%$ for core samples containing relatively low light hydrocarbon concentrations (Schaefer et al., 1978). It is assumed, however, that the standard deviation for thermovaporization yields is somewhat higher. We have indications that the yields obtained by our procedure represent nearly the absolute quantities of hydrocarbons present, both dissolved in the pore water and adsorbed on mineral surfaces. The modification of the method was necessary because several Site 585 samples turned out to be contaminated on board ship by varying amounts of acetone. The occurrence of large amounts of acetone in the light hydrocarbon fraction of DSDP cores (a problem never before realized by other workers in this field) should be avoided 
for the following reasons: First, it is reasonable to assume that the acetone used on board ship is not absolutely pure; other organic compounds may therefore contaminate the core samples. Second, the acetone peak in the gas chromatograms interferes with various compounds that are of geochemical interest. No contamination by acetone was observed, however, in the hydraulic-piston-cored (HPC) samples of Site 586. We believe that the tightness of the sediment core in the HPC liner prevents acetone from penetrating into the core during core-cutting procedures.

Organic carbon contents of the sediments were measured by a combustion method (LECO carbon analyzer IR 112) after treatment with hot $6 \mathrm{~N} \mathrm{HCl}$ on the same samples used for low-molecular-weight hydrocarbon determination. The accuracy of the organic-carbon determination is still rather high at organic-carbon levels of $0.1 \%$ or even less $(10 \%$ relative standard deviation). Values near $0.01 \%$, however, although still above the detection limit, are considered with caution in the following discussion.

Data on kerogen qualities were obtained for selected Site 585 samples by Rock-Eval pyrolysis (Espitalié et al., 1977).

\section{SITE 585}

\section{Regional Setting}

Drilling at Site 585 in the East Mariana Basin at a water depth of $6109 \mathrm{~m}$ (geographical coordinates $13^{\circ}$ $29.00^{\prime} \mathrm{N}, 156^{\circ} 48.91^{\prime} \mathrm{E}$, see Fig. 1) penetrated the sedimentary sequence described next (for further details see the Site 585 report-this volume).

Unit I: 0-7 m, nannofossil ooze and brown clay (Pleistocene).

Unit II: 256-399 m, nannofossil chalk, siliceous limestone, chert, and zeolitic claystone (middle Eocene to Maestrichtian).

Unit III: $399-426 \mathrm{~m}$, zeolitic claystone, with nannofossil claystone, chalk, and chert (Maestrichtian and upper Campanian).

Unit IV: 426-485 m, chert and zeolitic claystone (Campanian).

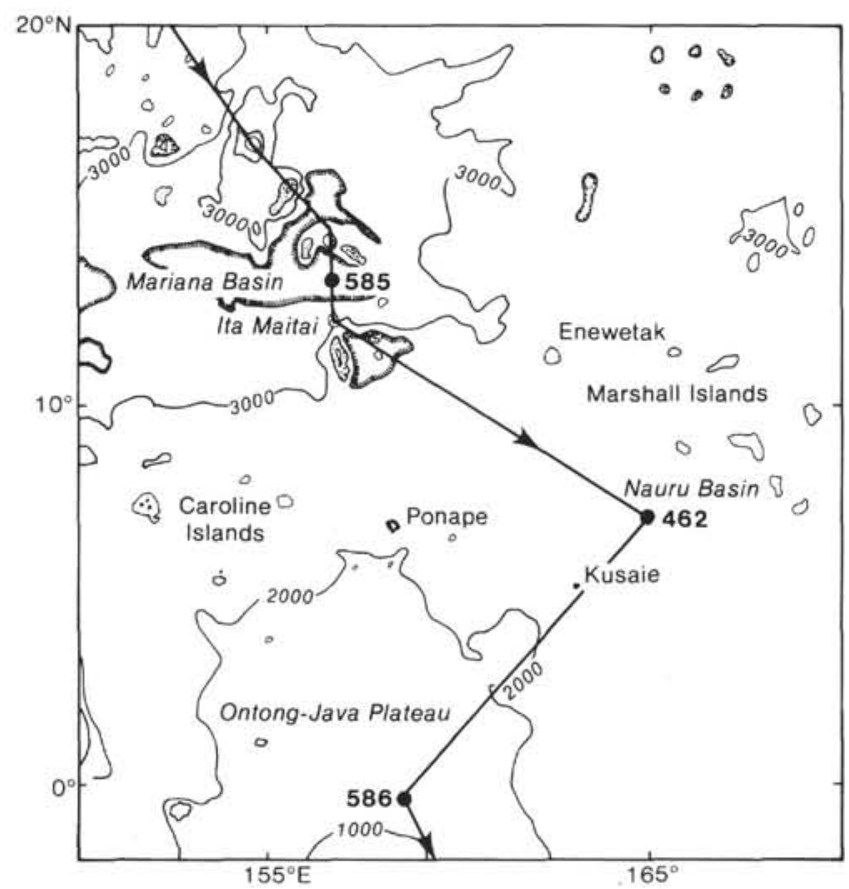

Figure 1. Locations of DSDP Leg 89 Sites 585, 462, and 586.
Unit V: 485-590 m, claystone, locally with significant zeolites, graded radiolarian fine sands, thin laminae rich in organic carbon, and carbonate (Campanian to middle Albian).

Unit VI: 590-893 m, volcanogenic sandstones, mudstones, and breccias, with admixtures of shallow-water debris (middle Albian to upper Aptian).

Benthic foraminiferal fauna indicated that the East Mariana Basin was at abyssal depths from the Aptian to the present (Sliter, this volume).

\section{Results and Discussion}

\section{Characterization of Organic Matter}

Organic-carbon contents (Table 1, Fig. 2) are extremely low in most of the samples analyzed (ranging from $0.05-0.13 \%$ ). Significantly elevated organic-carbon values (up to $0.3 \%$ ) were measured in only three samples of Lithologic Subunit VB (Cores 585-32 and 585A-8). The three samples are dark gray, slightly calcareous claystones with abundant plant fragments occurring as black pyritized flecks or flakes, scattered throughout the rock matrix and oriented subparallel to stratification. These samples were taken in close proximity (see Table 1) to the two thin black-shale layers encountered at $534.92 \mathrm{~m}$ (Hole 585 ) and $536.47 \mathrm{~m}$ (Hole 585A) sub-bottom depth. Deposition of these algal-kerogen-rich layers at or very close to the Cenomanian/Turonian boundary is interpreted to be the result of the short-term global Cenomanian/Turonian "Oceanic Anoxic Event" (Schlanger and Jenkyns, 1976). This event is now known to have left its record in sedimentary sequences of the Atlantic basin, the Tethys, the American Western Interior Basin, the northwestern European shelf and west African marginal basins, as well as the Pacific basin (Jenkyns, 1980; Schlanger and Cita, 1982; Schlanger et al., in press). Recent studies by Thiede et al. (1982) and Dean et al. (1984) raised some doubt whether depositional environments of "anoxic" sediments in the Pacific Ocean require an isochronous oxygen depletion of the oceanic intermediate and deep water on a global scale.

Because of restrictions imposed by the curatorial representative on board ship, it was not possible to sample either one of the black-shale layers for the present study.

On the basis of the Rock-Eval pyrolysis results (Table 2 ), the three claystones of Lithologic Subunit VB with elevated organic-carbon contents have hydrogen indexes between 269 and $448 \mathrm{mg}$ hydrocarbons/g $\mathrm{C}_{\text {org }}$, characterizing them, according to Espitalié et al., (1977), as hydrogen-rich, type-II kerogens of algal origin (in particular, Samples 585-32-3, 1-2 cm and 585A-8-1, 149$150 \mathrm{~cm}$ ). $\mathrm{T}_{\max }$-values between 423 and $427^{\circ} \mathrm{C}$ indicate the low maturity of these kerogens (Herbin and Deroo, 1979).

\section{Light Hydrocarbon Contents}

Low-molecular-weight hydrocarbon concentrations normalized to rock weight (Fig. 2) are relatively low but variable over the entire depth interval studied. Total $\mathrm{C}_{2}-$ $\mathrm{C}_{8}$ hydrocarbon yields range from 20 to $630 \mathrm{ng} / \mathrm{g}$ dry sediment weight. The three samples of Lithologic Sub- 
unit VB with elevated organic carbon contents have values between 90 and $150 \mathrm{ng} / \mathrm{g}$. The highest value is measured in the very organic-carbon-poor claystone from $512.91 \mathrm{~m}$ sub-bottom depth (Sample 585-30-1, 1-2 cm), which has an organic-carbon content of $0.07 \%$.

The trend of organic-carbon normalized total $\mathrm{C}_{2}-\mathrm{C}_{8}$ hydrocarbon yield versus depth is similar to that of the corresponding data based on rock weight (Fig. 2). Yields range from $3 \times 10^{4}$ to $9 \times 10^{5} \mathrm{ng} / \mathrm{g} \mathrm{C}_{\text {org }}$. Values between $3 \times 10^{4}$ and $6 \times 10^{4} \mathrm{ng} / \mathrm{g} \mathrm{C}_{\text {org }}$ are measured in the claystones of Lithologic Subunit VB with elevated organic-carbon contents. Assuming that these concentrations are indigenous, we conclude that the organic matter at these depths is still in an initial diagenetic evolutionary stage (cf., Schaefer and Leythaeuser, 1984). The very high yield of nearly $10^{6} \mathrm{ng} / \mathrm{g} \mathrm{C}_{\text {org }}$ in Core $585-30$, however, appears to be due to enrichment in migrated hydrocarbons, preferentially in the gas compounds. In order to examine this hypothesis the concentration versus depth trends of two selected compounds, which differ considerably with respect to their mobility (e.g., by diffusion; see Leythaeuser et al., 1980, 1983), are compared: ethane (Fig. 3) and $n$-pentane (Fig. 4), representing compounds of high and low mobility, respectively. The ethane yield for Sample 585-30-1, 1-2 cm is as high as $63,200 \mathrm{ng} / \mathrm{g} \mathrm{C}_{\text {org }}$ whereas for the three claystones of Lithologic Subunit VB with elevated organic-carbon contents a mean value of $2490 \mathrm{ng} / \mathrm{g} \mathrm{C}_{\text {org }}$ is measured. For $n$-pentane the corresponding yields are 31,200 and 3890 $\mathrm{ng} / \mathrm{g} \mathrm{C}_{\text {org }}$, respectively. A comparison of these figures indicates that Sample 585-30-1, 1-2 cm contains a much higher relative proportion of ethane (ethane: $n$-pentane ratio $=2.0$ ) than the other samples (ratio 0.64 ). The particular abundance of the gas compounds in this sample is also obvious if the comparison is made based on rock-weight yields for all $n$-alkanes $\left(\mathrm{C}_{2}-\mathrm{C}_{8}\right)$. Hydrocarbon yields for Sample 585-30-1, 1-2 cm, divided by those of the organic-carbon-rich claystones of Table 2 (averaged values, see Table 1), give the following ratios: ethane (8.8), propane (13.0), $n$-butane (10.9), $n$-pentane (2.5), $n$-hexane (3.4), $n$-heptane (3.1), and $n$-octane (2.2). Obviously, the enrichment in ethane, propane, and $n$-butane is much more pronounced than for the higher-molecular-weight, gasoline-range $\left(\mathrm{C}_{5}-\mathrm{C}_{8}\right)$ hydrocarbons.

Although the influence of slight differences in the type of the organic matter between these samples cannot be ruled out, it is most likely that the very organiccarbon-poor sample of Core 585-30, in particular is enriched in gaseous hydrocarbons migrating through the sedimentary column.

It should be emphasized, however, that because of their very low organic-carbon contents as well as the reduced accuracy of organic-carbon determination at these levels, the organic-carbon normalized hydrocarbon yields are extremely sensitive to even the slightest hydrocarbon impregnation that in samples of higher organic-carbon content would not be significant. In this respect, conclusions regarding migration effects based on differences in carbon-normalized light hydrocarbon yields should be considered with caution. On the other hand, because migration effects were also recognized by comparison of concentrations based on rock weight, our interpretation appears warranted.

\section{SITE 586}

\section{Regional Setting}

Site 586 , originally planned for DSDP Leg 90 , was cored with the hydraulic piston corer (HPC) on the Ontong-Java Plateau at a water depth of $2207 \mathrm{~m}$ (geographical coordinates $00^{\circ} 29.84^{\prime} \mathrm{S}, 158^{\circ} 29.89^{\prime} \mathrm{E}$ ) in order to recover Neogene calcareous oozes for paleoceanographic studies in the southwestern Pacific. Nine samples (one from Hole 586 and eight from Hole 586A) ranging over the depth interval 27 to $298 \mathrm{~m}$ sub-bottom (Cores 586-4 to $586 \mathrm{~A}-30$ ) were chosen for organic-carbon and lowmolecular-weight hydrocarbon determination (Table 3).

\section{Results and Discussion}

Organic-carbon contents are extremely low, ranging from 0.04 to $0.17 \%$ (average $0.08 \%$ ) in this sequence. Accordingly, total $\mathrm{C}_{2}-\mathrm{C}_{8}$ hydrocarbon yields do not exceed $118 \mathrm{ng} / \mathrm{g}$ dry sediment weight (average $56 \mathrm{ng} / \mathrm{g}$ ), indicating the immaturity of the organic matter of these samples (Schaefer et al., 1983b).

\section{CONCLUSIONS}

The sample series analyzed was not ideal for the main scientific objective of our study. Because of the lack of suitable sequences of interbedded organic-carbon-rich and -poor strata, the questions of whether light hydrocarbon redistribution is initiated during early diagenetic stages could not be examined properly. However, we recognized in one sample (Core 585-30) a significant enrichment in gaseous hydrocarbons that probably migrated from nearby black-shale source layers. This conclusion is based on a comparison of yields of selected light hydrocarbon compounds with pronounced differences in their individual mobilities between adjacent samples.

For the remaining samples geochemical interpretation of the available data had to be restricted to the aspects of hydrocarbon generation and maturity.

On the basis of total light hydrocarbon yields, the entire sedimentary sequences of Sites 585 and 586 could be classified as immature. No particular depth-related maturity increase was observed.

\section{ACKNOWLEDGMENTS}

The U.S. National Science Foundation, which assisted us by supplying samples, and the financial support for this study by the Deutsche Forschungsgemeinschaft, Schwerpunkt "Deep Sea Drilling Project" (DFG Grant No. Le 469/1) are gratefully acknowledged.

We would like to thank Dr. P. J. Müller for the organic-carbon and Rock-Eval pyrolysis measurements. Technical assistance by U. Disko, Mrs. M. Derichs, H. Hardelauf, M. Landgraf, H. Pooch, and H.-G. Sittardt (all at KFA Jülich) is gratefully appreciated. Mrs. B. Schmitz typed the manuscript.

One of the authors (R.G.S.) is most grateful to the U.S. National Science Foundation and the JOIDES Organic Geochemistry Panel for the invitation to participate as shipboard organic geochemist in the DSDP Leg 89 cruise, and to the Deutsche Forschungsgemeinschaft for providing the travel funds.

Critical reviews by Dr. G. E. Claypool and by an anonymous reviewer are gratefully acknowledged. 
Table 1. Summary of low-molecular-weight hydrocarbon concentrations and organic carbon contents of samples from DSDP Site 585.

\begin{tabular}{|c|c|c|c|c|c|c|c|}
\hline & \multicolumn{7}{|c|}{$\begin{array}{l}\text { Sample }{ }^{\mathrm{a}} \text { and description } \\
\text { [sub-bottom depth }(\mathrm{m}) \text { ] }\end{array}$} \\
\hline & $\begin{array}{c}585-11-2,7-8 \\
{[331.87]}\end{array}$ & $\begin{array}{c}585-20-2,1-2 \\
{[418.51]}\end{array}$ & $\begin{array}{c}585-20-3,1-2 \\
{[420.01]}\end{array}$ & $\begin{array}{c}585-27-2,1-2 \\
{[486.91]}\end{array}$ & $\begin{array}{c}585-27-3,1-2 \\
{[488.41]}\end{array}$ & $\begin{array}{c}585-28-2,1-2 \\
{[496.11]}\end{array}$ & $\begin{array}{c}585-28-2,149-150 \\
{[497.59]}\end{array}$ \\
\hline & $\begin{array}{l}\text { Nannofossil } \\
\text { chalk }\end{array}$ & $\begin{array}{l}\text { Zeolitic } \\
\text { claystone }\end{array}$ & $\begin{array}{l}\text { Zeolitic } \\
\text { claystone }\end{array}$ & $\begin{array}{l}\text { Zeolite- } \\
\text { bearing } \\
\text { claystone }\end{array}$ & $\begin{array}{l}\text { Zeolite- } \\
\text { bearing } \\
\text { claystone }\end{array}$ & $\begin{array}{l}\text { Zeolite- } \\
\text { bearing } \\
\text { claystone }\end{array}$ & $\begin{array}{l}\text { Zeolite- } \\
\text { bearing } \\
\text { claystone }\end{array}$ \\
\hline $\mathrm{C}_{\text {org }}$ (\% dry sediment weight) & 0.13 & 0.09 & 0.11 & 0.07 & 0.05 & 0.07 & 0.08 \\
\hline \multicolumn{8}{|l|}{ Hydrocarbon (ng/g dry sediment weight) } \\
\hline Ethene & 6.3 & 4.4 & 2.7 & 2.8 & 2.7 & 4.3 & 4.9 \\
\hline Ethane & 13.5 & 21.8 & 12.2 & 14.4 & 11.2 & 30.6 & 14.4 \\
\hline Propene & 14.0 & 7.7 & 3.6 & 5.2 & 4.1 & 4.3 & 7.7 \\
\hline Propane & 10.3 & 35.9 & 17.2 & 37.8 & 30.8 & 45.9 & 41.8 \\
\hline Methylpropane & 2.3 & 16.5 & 4.8 & 17.3 & 11.8 & 14.8 & 18.7 \\
\hline Methylpropene + 1-butene & 7.9 & 6.4 & 3.7 & 11.3 & 13.3 & 5.5 & 16.7 \\
\hline$n$-Butane & 5.4 & 19.6 & 8.7 & 18.4 & 14.1 & 24.5 & 22.2 \\
\hline trans-2-butene & 1.5 & 1.7 & 0.80 & 1.9 & 1.8 & 1.4 & 2.8 \\
\hline 2,2-Dimethylpropane & $<0.01$ & 0.02 & $<0.01$ & 0.02 & 0.06 & 0.07 & 0.10 \\
\hline cis-2-butene & 1.5 & 1.2 & 0.61 & 1.4 & 1.5 & 1.2 & 2.5 \\
\hline Methylbutane & 1.7 & 10.5 & 3.0 & 11.0 & 8.6 & 10.3 & 13.0 \\
\hline n-Pentane & 4.3 & 11.8 & 5.8 & 7.5 & 4.6 & 14.1 & 9.8 \\
\hline 2,2-Dimethylbutane & - & - & - & - & - & - & - \\
\hline Cyclopentane & $<0.1$ & 0.80 & 0.38 & 0.29 & $<0.1$ & 1.2 & 0.33 \\
\hline 2,3-Dimethylbutane & - & $<0.1$ & $<0.1$ & $<0.1$ & $<0.1$ & 0.33 & 0.17 \\
\hline 2-Methylpentane & 0.64 & 2.9 & 0.81 & 2.2 & 1.6 & 3.1 & 2.9 \\
\hline 3-Methylpentane & $<0.1$ & 0.17 & $<0.1$ & 0.12 & 0.96 & 2.2 & 1.9 \\
\hline$n$-Hexane & 3.1 & 9.3 & 5.5 & 7.2 & 4.6 & 11.8 & 9.3 \\
\hline Methylcyclopentane + 2,2-dimethylpentane & $<0.1$ & $<0.1$ & $<0.1$ & 0.79 & - & - & - \\
\hline 2,4-Dimethylpentane & - & - & - & - & - & - & - \\
\hline Benzene & 3.2 & 5.9 & 5.1 & 7.0 & 5.8 & 10.4 & 12.1 \\
\hline Cyclohexane & $<0.1$ & $<0.1$ & $<0.1$ & $<0.1$ & $<0.1$ & 0.33 & $<0.1$ \\
\hline 2-Methylhexane & $<0.1$ & 0.29 & $<0.1$ & $<0.1$ & 0.46 & 2.6 & 0.85 \\
\hline 2,3-Dimethylpentane + 1,1-dimethylcyclopentane & - & $<0.1$ & $<0.1$ & $<0.1$ & - & 0.10 & 0.63 \\
\hline 3-Methylhexane & $<0.1$ & $<0.1$ & 0.12 & 0.18 & $<0.1$ & 2.8 & 0.60 \\
\hline 1,cis-3-dimethylcyclopentane & $<0.1$ & 0.11 & $<0.1$ & $<0.1$ & 0.50 & 0.93 & 1.0 \\
\hline 1,trans-3-dimethylcyclopentane & $<0.1$ & $<0.1$ & $<0.1$ & $<0.1$ & $<0.1$ & $<0.1$ & - \\
\hline 1,trans-2-dimethylcyclopentane & - & $<0.1$ & $<0.1$ & $<0.1$ & - & $<0.1$ & - \\
\hline$n$-Heptane & 1.8 & 6.4 & 2.7 & 3.5 & 3.4 & 9.9 & 7.0 \\
\hline 1,cis-2-dimethylcyclopentane & - & $<0.1$ & - & - & - & - & $<0.1$ \\
\hline Methylcyclohexane & $<0.1$ & $<0.1$ & - & $<0.1$ & $<0.1$ & $<0.1$ & $<0.1$ \\
\hline 2,5-Dimethylhexane & - & - & - & - & - & - & - \\
\hline Ethylcyclopentane & $<0.1$ & $<0.1$ & - & - & - & $<0.1$ & $<0.1$ \\
\hline 1, trans-2,cis-4-trimethylcyclopentane & - & - & $<0.1$ & $<0.1$ & - & - & - \\
\hline 1,trans-2,cis-3-trimethylcyclopentane & - & - & $<0.1$ & - & $<0.1$ & - & - \\
\hline Toluene & 8.0 & 32.6 & 12.8 & 61.6 & 48.8 & 29.2 & 71.3 \\
\hline 2-Methylpentane & - & - & - & - & - & - & - \\
\hline$n$-Octane & 3.2 & 7.0 & 4.4 & 7.1 & 3.8 & 7.8 & 9.8 \\
\hline
\end{tabular}

Note: $-=$ concentration below or near detection limit, $+=$ value uncertain due to peak overlapping.

a Sample number shows hole-core-section, $\mathrm{cm}$ interval.

\section{REFERENCES}

Dean, W. E., Claypool, and Thiede, J., 1984. Accumulation of organic matter in Cretaceous oxygen-deficient depositional environments in the central Pacific Ocean. Org. Geochem., 7:39-51.

Espitalié, J., Laporte, J. L., Madec, M., Marquis, F., Leplat, P., Paulet, J., and Boutefeu, A., 1977. Méthode rapide de caractérisation des roches mères, de leur potentiel pétrolier et de leur degré d'évolution. Rev. Inst. Fr. Pet., 32:23-42.

Herbin, J. P., and Deroo, G., 1979. Etude sédimentologique de la matière organique dans les argiles noires crétacées de l'atlantique sud. Docum. Lab. Géol. Fac. Sci. Lyon, 75:71-87.

Jenkyns, H. C., 1980. Cretaceous anoxic events: from continents to oceans. J. Geol. Soc. London, 137:171-188.

Leythaeuser, D., Schaefer, R. G., and Pooch, H., 1983. Diffusion of light hydrocarbons in subsurface sedimentary rocks. Am. Assoc. Pet. Geol. Bull., 67:889-895.

Leythaeuser, D., Schaefer, R. G., and Yükler, A., 1980. Diffusion of light hydrocarbons through near-surface rocks. Nature (London), 284:522-525.

Schaefer, R. G., and Leythaeuser, D., 1984. $\mathrm{C}_{2}-\mathrm{C}_{8}$ hydrocarbons in sediments from Deep Sea Drilling Project Leg 75, Holes 530A, Angola Basin, and 532, Walvis Ridge. In Hay, W. W., Sibuet, J.-C., et al., Init. Repts. DSDP, 75: Washington (U.S. Govt. Printing Office), $1055-1067$.
Schaefer, R. G., Leythaeuser, D., and Gormly, J., 1984. Generation and migration of low-molecular-weight hydrocarbons in sediments of Deep Sea Drilling Project Leg 79, Sites 544, 545, and 547, offshore Morocco. In Hinz, K., Winterer, E. L., et al., Init. Repts. DSDP, 79: Washington (U.S. Govt. Printing Office), 743-773.

Schaefer, R. G., Leythaeuser, D., and von der Dick, H., 1983a. Generation and migration of low-molecular-weight hydrocarbons in sediments from Site 511 of DSDP/IPOD Leg 71, Falkland Plateau, South Atlantic. In Bjorøy, M. (Ed.), Advances in Organic Geochemistry 1981: Chichester (Wiley), pp. 164-174.

Schaefer, R. G., von der Dick, H., and Leythaeuser, D., 1983b. $\mathrm{C}_{2}-\mathrm{C}_{8}$ hydrocarbons in sediments from Deep Sea Drilling Project Leg 71 , Site 511, Falkland Plateau, South Atlantic. In Ludwig, W. J., Krasheninnikov, V., et al., Init. Repts. DSDP, 71: Washington (U.S. Govt. Printing Office), 1033-1043.

Schaefer, R. G., Weiner, B., and Leythaeuser, D., 1978. Determination of sub-nanogram per gram quantities of light hydrocarbons $\left(\mathrm{C}_{2}-\mathrm{C}_{9}\right)$ in rock samples by hydrogen stripping in the flow system of a capillary gas chromatograph. Anal. Chem., 50:1848-1854.

Schlanger, S. O., Arthur, M. A., Jenkyns, H. C., and Scholle, P. D., in press. The Cenomanian-Turonian Oceanic Anoxic Event. I. Stratigraphy and distribution of organic carbon-rich beds and the marine $\delta^{13} \mathrm{C}$ excursion. In Brooks, J., and Fleet, A. (Eds.), Geol. Soc. London Spec. Publ., Marine Petroleum Source Rocks: Oxford (Blackwells). 
Table 1 (continued).

\begin{tabular}{|c|c|c|c|c|c|c|c|c|}
\hline \multicolumn{9}{|c|}{$\begin{array}{l}\text { Sample }{ }^{\mathrm{a}} \text { and description } \\
\text { [sub-bottom depth }(\mathrm{m})]\end{array}$} \\
\hline $\begin{array}{l}585-28-4,1-2 \\
{[499.11]}\end{array}$ & $\begin{array}{l}585-29-2,1-2 \\
{[505.21]}\end{array}$ & $\begin{array}{l}585-30-1,1-2 \\
{[512.91]}\end{array}$ & $\begin{array}{c}585-31-3,149-150 \\
{[526.49]}\end{array}$ & $\begin{array}{l}\text { 585A-8-1, } 1-2 \\
{[532.41]}\end{array}$ & $\begin{array}{c}\text { 585A-8-1, 149-150 } \\
{[533.89]}\end{array}$ & $\begin{array}{l}585-32-3,1-2 \\
{[534.21]}\end{array}$ & $\begin{array}{c}\text { 585A-8-3, } 1-2 \\
{[535.41]}\end{array}$ & $\begin{array}{c}\text { 585A-8,CC (19-20) } \\
{[536.37]}\end{array}$ \\
\hline $\begin{array}{c}\text { Zeolite- } \\
\text { bearing } \\
\text { claystone }\end{array}$ & Claystone & Claystone & Claystone & Claystone & Claystone & Claystone & Claystone & Claystone \\
\hline 0.07 & 0.08 & 0.07 & 0.07 & 0.08 & 0.29 & 0.18 & 0.26 & 0.06 \\
\hline 3.8 & 4.8 & 5.6 & 2.7 & 1.5 & 2.6 & 3.9 & 4.5 & 1.8 \\
\hline 6.3 & 17.5 & 44.2 & 17.8 & 1.1 & 2.2 & 10.3 & 2.6 & 1.4 \\
\hline 4.9 & 7.5 & 9.7 & 5.1 & 1.4 & 3.3 & 4.0 & 2.9 & 0.84 \\
\hline 10.4 & 27.9 & 121.0 & 34.3 & 2.9 & 7.6 & 12.7 & 7.6 & 3.3 \\
\hline 3.7 & 12.9 & 61.2 & 9.9 & 1.8 & 1.2 & 3.1 & 3.9 & 3.2 \\
\hline 6.1 & 9.7 & 17.4 & 7.8 & 2.6 & 6.6 & 3.6 & 5.6 & 1.2 \\
\hline 6.0 & 13.3 & 59.5 & 15.1 & 1.8 & 5.8 & 6.1 & 4.5 & 3.3 \\
\hline 1.3 & 2.0 & 4.0 & 1.8 & 0.41 & 1.3 & 0.93 & 1.1 & 0.31 \\
\hline 0.05 & 0.07 & 0.19 & 0.04 & $<0.01$ & 0.07 & $<0.01$ & $<0.01$ & $<0.01$ \\
\hline 1.3 & 1.8 & 3.3 & 1.5 & 0.43 & 1.4 & 0.71 & 1.0 & 0.26 \\
\hline 2.8 & 9.4 & 39.2 & 5.5 & 1.4 & 4.8 & 3.8 & 4.3 & 7.9 \\
\hline 4.3 & 5.9 & 21.9 & 7.9 & 1.4 & 8.3 & 10.7 & 7.4 & 5.2 \\
\hline- & - & - & - & - & - & - & - & - \\
\hline$<0.1$ & 0.30 & 1.9 & 0.67 & 0.17 & 3.6 & 0.57 & 0.27 & 2.1 \\
\hline- & - & 0.32 & - & $<0.1$ & - & - & - & 0.98 \\
\hline 0.99 & 2.1 & 7.8 & 1.2 & 0.22 & 0.82 & 0.87 & 0.94 & 7.9 \\
\hline 0.93 & 1.3 & 4.4 & 1.4 & 0.21 & 1.1 & 0.95 & 0.80 & 5.3 \\
\hline 4.0 & 4.5 & 16.7 & 6.2 & 1.8 & 6.3 & 3.6 & + & 8.6 \\
\hline- & - & 3.2 & 0.52 & $<0.1$ & 0.51 & 0.88 & - & 10.6 \\
\hline - & - & 0.58 & - & $<0.1$ & $<0.1$ & $<0.1$ & - & 0.81 \\
\hline 4.6 & 6.1 & 17.5 & 6.6 & 1.1 & 2.6 & 3.4 & 3.4 & 6.2 \\
\hline$<0.1$ & $<0.1$ & 0.39 & $<0.1$ & $<0.1$ & 0.35 & 0.52 & 0.69 & 15.9 \\
\hline- & 0.58 & 2.9 & $<0.1$ & - & 0.94 & 0.85 & 1.0 & 5.5 \\
\hline 0.14 & 0.36 & 0.90 & $<0.1$ & $<0.1$ & 0.55 & 0.31 & 0.64 & 4.4 \\
\hline$<0.1$ & $<0.1$ & 2.1 & $<0.1$ & $<0.1$ & 1.2 & 1.1 & 1.5 & 7.2 \\
\hline$<0.1$ & 0.65 & 1.2 & $<0.1$ & 0.21 & 0.60 & 0.64 & 0.48 & 2.8 \\
\hline$<0.1$ & $<0.1$ & $<0.1$ & - & - & $<0.1$ & $<0.1$ & $<0.1$ & 3.9 \\
\hline- & - & $<0.1$ & $<0.1$ & - & $<0.1$ & 0.35 & $<0.1$ & 9.0 \\
\hline 3.3 & 3.8 & 12.3 & 4.1 & 1.2 & 5.1 & 3.1 & 3.6 & 13.4 \\
\hline- & - & - & - & - & $<0.1$ & - & $<0.1$ & 1.6 \\
\hline$<0.1$ & $<0.1$ & $<0.1$ & $<0.1$ & - & 0.92 & 0.57 & 2.1 & 32.2 \\
\hline- & - & - & $<0.1$ & - & - & - & - & $<0.1$ \\
\hline - & - & $<0.1$ & - & - & - & - & - & 5.7 \\
\hline - & - & - & - & - & - & - & $<0.1$ & 2.6 \\
\hline- & - & - & - & - & - & - & $<0.1$ & 4.3 \\
\hline 13.1 & 45.7 & 196.0 & 28.0 & 9.1 & 25.5 & 18.1 & 62.9 & 23.3 \\
\hline- & - & - & - & - & - & - & - & - \\
\hline 3.0 & $<0.1$ & 10.3 & 2.7 & 0.12 & 5.9 & 1.1 & 6.8 & 17.8 \\
\hline
\end{tabular}

Schlanger, S. O., and Cita, M. B. (Eds.), 1982. Nature and Origin of Cretaceous Carbon-rich Facies: London (Academic Press).

Schlanger, S. O., and Jenkyns, H. C., 1976. Cretaceous oceanic anoxic events: causes and consequences. Geol. Mijnbouw, 55:179-184.

Thiede, J., Dean W. E., and Claypool, G. E., 1982. Oxygen-deficient depositional paleoenvironments in the mid-Cretaceous tropical and subtropical Central Pacific Ocean. In Schlanger, S. O., and Cita, M. B. (Eds.), Nature and Origin of Cretaceous Carbon-rich Facies: London (Academic Press), pp. 79-100.
Whelan, J. K., and Hunt, J. M., 1981. C $1-C_{8}$ hydrocarbons in Leg 63 sediments from outer California and Baja California borderlands. In Yeats R. S., Haq, B. U., et al., Init. Repts. DSDP, 63: Washington (U.S. Govt. Printing Office), 775-784. 1982. $C_{1}-C_{8}$ hydrocarbons in Leg 64 sediments, Gulf of California. In Curray, J. R., Moore, D. G., et al., Init. Repts. DSDP, 64: Washington (U.S. Govt. Printing Office), 763-780.

Date of Acceptance: 26 November 1984 
Table 1 (continued).

\begin{tabular}{|c|c|c|c|c|c|c|}
\hline & \multicolumn{6}{|c|}{$\begin{array}{l}\text { Sample }{ }^{\mathrm{a}} \text { and description } \\
\text { [sub-bottom depth }(\mathrm{m}) \text { ] }\end{array}$} \\
\hline & $\begin{array}{l}\text { 585A-9-1, 1-2 } \\
{[543.51]} \\
\text { Siltstone }\end{array}$ & $\begin{array}{c}\text { 585-41,CC (10-11) } \\
\text { [617.90] } \\
\text { Volcano- } \\
\text { genic } \\
\text { silty } \\
\text { claystone }\end{array}$ & $\begin{array}{l}\text { 585-42-3, 1-2 } \\
{[630.01]} \\
\text { Volcano- } \\
\text { genic } \\
\text { calcareous } \\
\text { claystone }\end{array}$ & $\begin{array}{c}585-46-2,120-121 \\
{[670.50]} \\
\text { Volcani- } \\
\text { clastic } \\
\text { siltstone }\end{array}$ & $\begin{array}{l}\text { 585-49-6, 1-2 } \\
\text { [702.71] } \\
\text { Volcani- } \\
\text { clastic } \\
\text { siltstone }\end{array}$ & $\begin{array}{c}585-50-2,119-120 \\
{[707.90]} \\
\text { Volcani- } \\
\text { clastic } \\
\text { conglomerate } \\
\text { siltstone }\end{array}$ \\
\hline $\mathrm{C}_{\text {org }}(\%$ dry sediment weight $)$ & 0.07 & 0.07 & 0.12 & 0.06 & 0.06 & 0.07 \\
\hline \multicolumn{7}{|l|}{ Hydrocarbon ( $\mathrm{ng} / \mathrm{g}$ dry sediment weight) } \\
\hline Ethene & 3.4 & 0.98 & 0.81 & - & 1.7 & 1.5 \\
\hline Ethane & 2.9 & 0.93 & 4.9 & 9.3 & 3.0 & 6.6 \\
\hline Propene & 2.4 & 0.82 & 0.96 & - & 2.5 & 2.4 \\
\hline Propane & 8.6 & 2.7 & 9.5 & 13.4 & 8.8 & 10.6 \\
\hline Methylpropane & 4.2 & 1.8 & 3.2 & 3.8 & 3.8 & 3.4 \\
\hline Methylpropene + 1-butene & 1.6 & 2.6 & 2.0 & - & 5.4 & 2.0 \\
\hline$n$-Butane & 4.4 & 3.2 & 3.5 & 6.4 & 4.7 & 4.1 \\
\hline trans-2-butene & 0.91 & 0.53 & 0.36 & - & 0.83 & 0.47 \\
\hline 2,2-Dimethylpropane & 0.08 & 0.01 & 0.01 & 0.01 & 0.04 & $<0.01$ \\
\hline cis-2-butene & 0.75 & 0.62 & 0.33 & - & 0.88 & 0.25 \\
\hline Methylbutane & 2.2 & 2.1 & 1.8 & 2.2 & 2.8 & 1.9 \\
\hline$n$-Pentane & $<0.01$ & 2.8 & 1.5 & 3.7 & 1.8 & 3.3 \\
\hline 2,2-Dimethylbutane & - & 0.77 & 0.01 & 1.5 & - & - \\
\hline Cyclopentane & - & 0.47 & 0.17 & 0.28 & 0.15 & 0.13 \\
\hline 2,3-Dimethylbutane & $<0.1$ & - & - & - & - & $<0.1$ \\
\hline 2-Methylpentane & 0.28 & 0.55 & 0.41 & 0.71 & 0.55 & 0.72 \\
\hline 3-Methylpentane & 0.32 & 0.92 & 0.26 & 0.61 & 0.50 & 0.82 \\
\hline$n$-Hexane & 5.7 & 2.5 & 1.3 & 3.2 & 2.0 & 5.1 \\
\hline Methylcyclopentane + 2,2-dimethylpentane & $<0.1$ & $<0.1$ & $<0.1$ & 0.55 & 0.11 & 1.8 \\
\hline 2,4-Dimethylpentane & - & $<0.1$ & $<0.1$ & - & - & 0.41 \\
\hline Benzene & 1.8 & 2.8 & 2.1 & 2.7 & 3.0 & 2.7 \\
\hline Cyclohexane & $<0.1$ & $<0.1$ & $<0.1$ & $<0.1$ & $<0.1$ & $<0.1$ \\
\hline 2-Methylhexane & 0.39 & $<0.1$ & 0.52 & 0.38 & 0.38 & 2.4 \\
\hline 2,3-Dimethylpentane + 1,1-dimethylcyclopentane & $<0.1$ & $<0.1$ & $<0.1$ & $<0.1$ & - & 0.91 \\
\hline 3-Methylhexane & $<0.1$ & $<0.1$ & 0.37 & 0.41 & $<0.1$ & 2.8 \\
\hline 1,cis-3-dimethylcyclopentane & 0.14 & - & $<0.1$ & 0.18 & $<0.1$ & 0.54 \\
\hline 1,trans-3-dimethylcyclopentane & - & - & - & $<0.1$ & - & $<0.1$ \\
\hline 1,trans-2-dimethylcyclopentane & - & $<0.1$ & - & $<0.1$ & 0.22 & $<0.1$ \\
\hline$n$-Heptane & 2.7 & 4.7 & 1.1 & 2.6 & 1.5 & 6.7 \\
\hline 1,cis-2-dimethylcyclopentane & - & - & - & - & - & $<0.1$ \\
\hline Methylcyclohexane & - & - & $<0.1$ & - & $<0.1$ & $<0.1$ \\
\hline 2,5-Dimethylhexane & - & - & - & - & - & $<0.1$ \\
\hline Ethylcyclopentane & - & - & - & - & - & $<0.1$ \\
\hline 1,trans-2,cis-4-trimethylcyclopentane & - & - & $<0.1$ & - & - & - \\
\hline 1,trans-2,cis-3-trimethylcyclopentane & - & - & - & - & - & $<0.1$ \\
\hline Toluene & 21.0 & 12.6 & 8.4 & 7.9 & 20.5 & 13.0 \\
\hline 2-Methylpentane & - & - & - & - & - & - \\
\hline$n$-Octane & 2.8 & 2.8 & $<0.1$ & 3.1 & 57.8 & 4.9 \\
\hline
\end{tabular}


Table 1 (continued).

\begin{tabular}{|c|c|c|c|c|c|c|}
\hline \multicolumn{7}{|c|}{$\begin{array}{l}\text { Sample }^{a} \text { and description } \\
\text { [sub-bottom depth }(\mathrm{m})]\end{array}$} \\
\hline $\begin{array}{c}585-52-4,1-2 \\
{[727.21]}\end{array}$ & $\begin{array}{c}585-55-5,1-2 \\
{[756.11]}\end{array}$ & $\begin{array}{c}585 \mathrm{~A}-12-3,1-2 \\
{[784.31]}\end{array}$ & $\begin{array}{c}585 \mathrm{~A}-12-6,1-2 \\
{[788.81]}\end{array}$ & $\begin{array}{c}585 \mathrm{~A}-16-3,149-150 \\
{[831.49]}\end{array}$ & $\begin{array}{c}585 \mathrm{~A}-18-3,149-150 \\
{[852.09]}\end{array}$ & $\begin{array}{c}\text { 585A-20-1, 149-150 } \\
\text { [868.39] } \\
\text { Volcano- }\end{array}$ \\
\hline $\begin{array}{l}\text { Volcano- } \\
\text { genic } \\
\text { sandstone }\end{array}$ & Claystone & $\begin{array}{l}\text { Volcani- } \\
\text { clastic } \\
\text { siltstone }\end{array}$ & $\begin{array}{l}\text { Volcani- } \\
\text { clastic } \\
\text { siltstone }\end{array}$ & $\begin{array}{l}\text { Volcani- } \\
\text { clastic } \\
\text { siltstone }\end{array}$ & $\begin{array}{l}\text { Volcani- } \\
\text { clastic } \\
\text { sandstone }\end{array}$ & $\begin{array}{c}\text { genic } \\
\text { conglo- } \\
\text { merate }\end{array}$ \\
\hline 0.06 & 0.07 & 0.06 & 0.06 & 0.10 & 0.07 & 0.05 \\
\hline 1.6 & 2.2 & 0.95 & 1.9 & 1.5 & 4.2 & 0.86 \\
\hline 5.7 & 6.9 & 0.60 & 1.8 & 1.3 & 1.4 & 0.95 \\
\hline 4.1 & 3.0 & 1.5 & 1.6 & 1.7 & 4.9 & 1.5 \\
\hline 16.1 & 20.4 & 1.4 & 5.6 & 3.4 & 2.5 & 2.1 \\
\hline 6.8 & 9.0 & 1.1 & 2.8 & 2.3 & 1.5 & 1.7 \\
\hline 9.5 & 6.2 & 2.0 & 2.6 & 2.7 & 9.6 & 2.3 \\
\hline 8.8 & 10.1 & 1.1 & 2.9 & 2.1 & 1.8 & 1.4 \\
\hline 1.2 & 1.2 & 0.44 & 0.49 & 0.64 & 1.2 & 0.55 \\
\hline 0.04 & $<0.01$ & $<0.01$ & 0.03 & $<0.01$ & 1.0 & $<0.01$ \\
\hline 1.2 & 1.1 & 0.33 & 0.56 & 0.64 & 0.34 & 0.51 \\
\hline 5.8 & 6.0 & 0.55 & 1.6 & 1.2 & 1.2 & 0.77 \\
\hline 4.4 & 4.1 & 1.3 & 1.4 & 1.9 & 1.6 & 0.93 \\
\hline- & 1.3 & - & - & - & - & 1.5 \\
\hline- & 0.34 & - & - & 0.51 & 0.17 & 0.16 \\
\hline- & $<0.1$ & - & - & - & - & - \\
\hline 0.80 & 1.0 & 0.11 & 0.31 & 0.23 & 0.16 & 0.25 \\
\hline 3.9 & 0.97 & $<0.1$ & 0.22 & $<0.1$ & 2.8 & 0.34 \\
\hline 5.2 & 3.5 & 2.1 & 2.5 & 2.8 & 2.5 & 1.5 \\
\hline$<0.1$ & $<0.1$ & 0.12 & 0.16 & $<0.1$ & $<0.1$ & 0.22 \\
\hline$<0.1$ & $<0.1$ & - & $<0.1$ & $<0.1$ & $<0.1$ & $<0.1$ \\
\hline 12.3 & 4.5 & 0.40 & 1.3 & 1.3 & 1.8 & 0.78 \\
\hline$<0.1$ & - & - & $<0.1$ & - & $<0.1$ & 0.22 \\
\hline 0.77 & 0.42 & $<0.1$ & 0.46 & 0.84 & - & $<0.1$ \\
\hline 0.43 & 0.29 & $<0.1$ & 0.33 & 0.37 & $<0.1$ & $<0.1$ \\
\hline 0.90 & $<0.1$ & $<0.1$ & 0.66 & 1.00 & $<0.1$ & $<0.1$ \\
\hline 3.6 & 0.43 & $<0.1$ & $<0.1$ & $<0.1$ & - & $<0.1$ \\
\hline - & - & - & $<0.1$ & - & $<0.1$ & $<0.1$ \\
\hline- & - & - & - & - & - & $<0.1$ \\
\hline 4.8 & 2.9 & 0.97 & 1.8 & 1.9 & 2.6 & $<0.1$ \\
\hline- & - & - & - & - & - & - \\
\hline - & - & $<0.1$ & - & - & $<0.1$ & $<0.1$ \\
\hline- & - & - & - & - & $<0.1$ & - \\
\hline - & - & - & - & - & $<0.1$ & $<0.1$ \\
\hline$<0.1$ & - & - & - & - & - & - \\
\hline$<0.1$ & - & - & - & - & $<0.1$ & - \\
\hline 44.6 & 36.8 & 32.1 & 16.7 & 11.0 & 4.3 & 6.2 \\
\hline- & - & - & - & - & - & - \\
\hline 5.0 & 2.5 & 2.2 & 0.31 & 2.4 & 2.1 & 0.17 \\
\hline
\end{tabular}



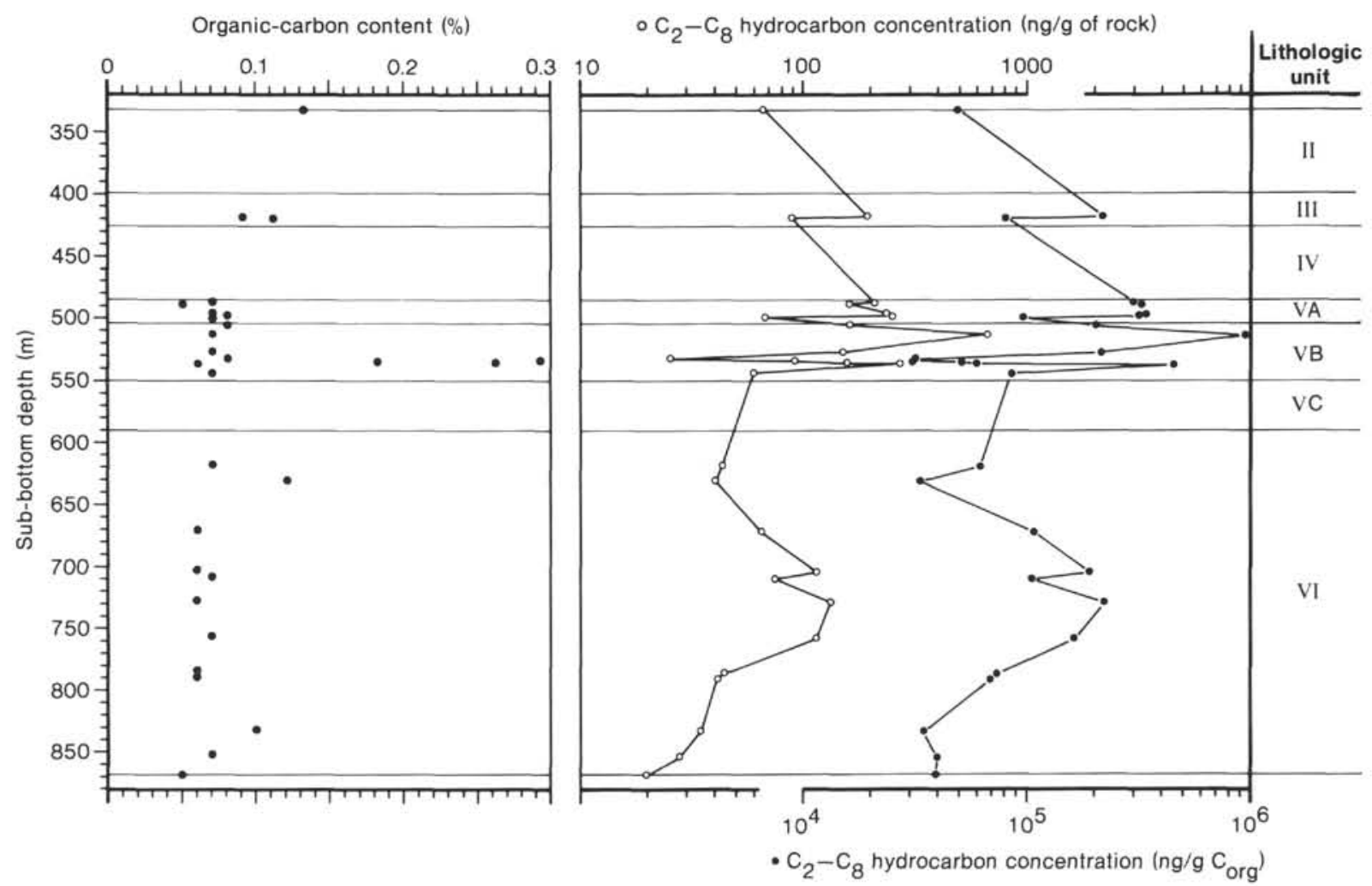

Figure 2. Organic-carbon content and low-molecular-weight hydrocarbon concentration (sum of all $\mathrm{C}_{2}-\mathrm{C}_{8}$ hydrocarbons identified in Table 1, except the olefins) versus sub-bottom depth for sediment samples from DSDP Site 585, Leg 89. 


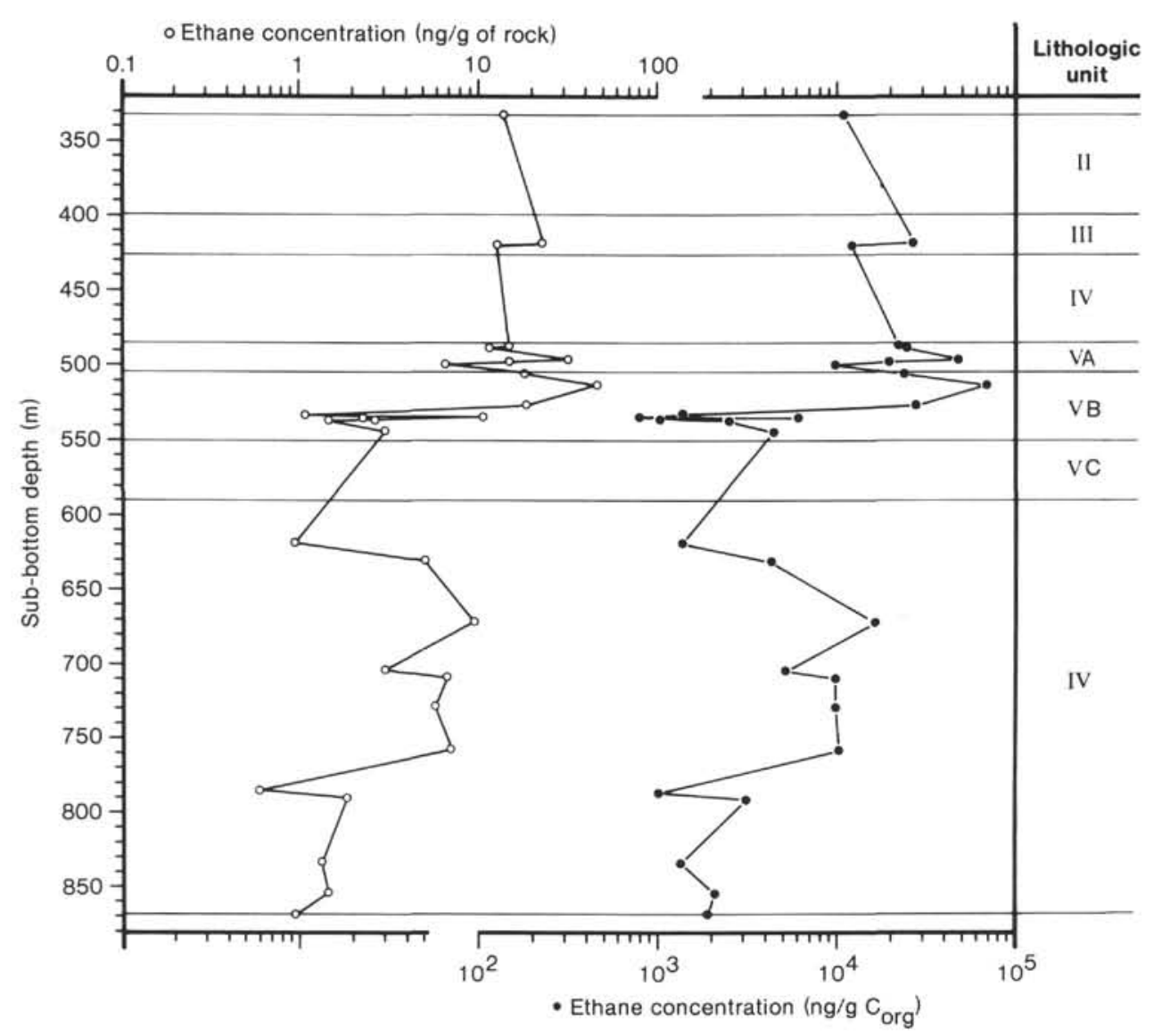

Figure 3. Ethane concentration versus sub-bottom depth for sediment samples from DSDP Site 585, Leg 89.

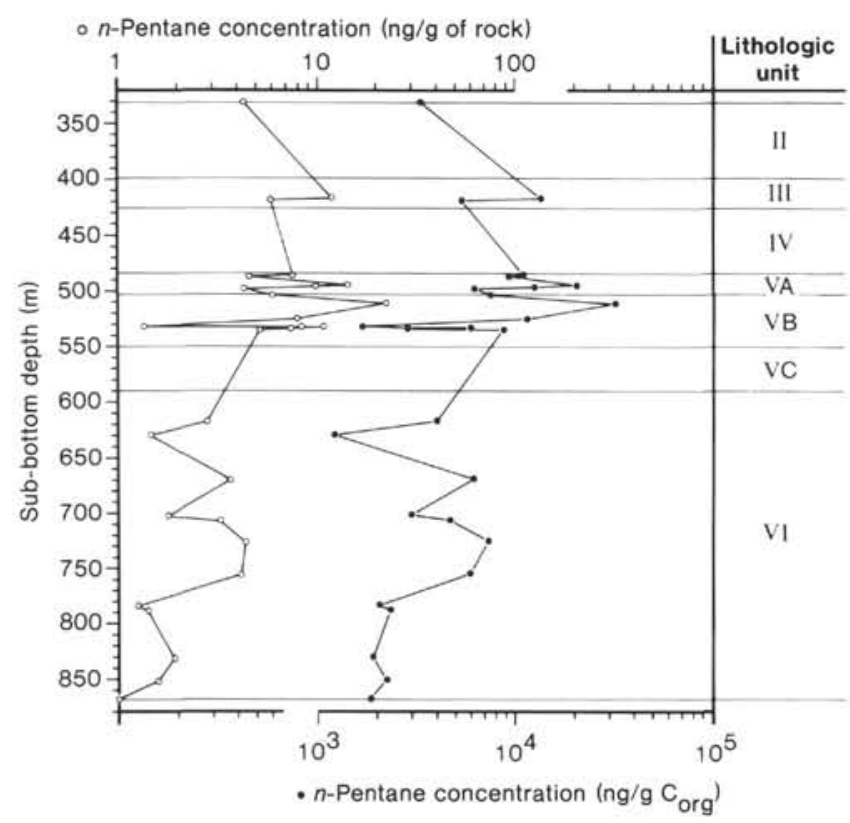

Table 2. Rock-Eval pyrolysis data of sediment samples with elevated organic-carbon contents of Lithologic Subunit VB (Site $585)$.

\begin{tabular}{lcccc}
\hline $\begin{array}{c}\text { Sample } \\
\text { (hole-core-section, } \\
\text { cm interval) }\end{array}$ & $\begin{array}{c}\text { Sub-bottom } \\
\text { depth (m) }\end{array}$ & $\begin{array}{c}\mathrm{C}_{\text {org }} \\
(\%)\end{array}$ & $\begin{array}{c}\text { Hydrogen index } \\
\left(\mathrm{mg} \mathrm{HC} / \mathrm{g} \mathrm{C}_{\text {org }}\right)\end{array}$ & $\begin{array}{c}\mathrm{T}_{\max } \mathrm{b} \\
\left({ }^{\circ} \mathrm{C}\right)\end{array}$ \\
\hline $585 \mathrm{~A}-8-1,149-150$ & 533.89 & 0.29 & 356 & .426 \\
$585-32-3,1-2$ & 534.21 & 0.18 & 448 & 427 \\
$585 \mathrm{~A}-8-3,1-2^{\mathrm{a}}$ & 535.41 & 0.30 & 269 & 426 \\
& & 0.26 & 341 & 423 \\
\hline
\end{tabular}

a Sample analyzed in duplicate.

b According to Espitalié et al. (1977).

Figure 4. $n$-Pentane concentration versus sub-bottom depth for sediment samples from DSDP Site 585, Leg 89. 
Table 3. Summary of low-molecular-weight hydrocarbon concentrations and organic carbon contents of samples from DSDP Site 586.

\begin{tabular}{|c|c|c|c|c|c|c|c|c|c|}
\hline & \multicolumn{9}{|c|}{$\begin{array}{l}\text { Sample }^{a} \text { and description } \\
\text { [sub-bottom depth }(\mathrm{m})]\end{array}$} \\
\hline & $\begin{array}{c}586-4-2,1-2 \\
{[26.91]} \\
\text { Foraminifer- } \\
\text { bearing } \\
\text { nannofossil } \\
\text { ooze }\end{array}$ & $\begin{array}{c}\text { 586A-12-5, } 149-150 \\
{[157.49]} \\
\text { Foraminifer- } \\
\text { bearing } \\
\text { nannofossil } \\
\text { ooze }\end{array}$ & $\begin{array}{c}\text { 586A-14-3, 1-2 } \\
\text { [169.91] } \\
\text { Foraminifer- } \\
\text { bearing } \\
\text { nannofossil } \\
\text { ooze }\end{array}$ & $\begin{array}{c}\text { 586A-15-3, 1-2 } \\
\text { [174.81] } \\
\text { Foraminifer- } \\
\text { bearing } \\
\text { nannofossil } \\
\text { ooze }\end{array}$ & $\begin{array}{c}\text { 586A-18-5, 1-2 } \\
\text { [206.01] } \\
\text { Foraminifer- } \\
\text { bearing } \\
\text { nannofossil } \\
\text { ooze }\end{array}$ & $\begin{array}{c}\text { 586A-20-5, 1-2 } \\
\text { [224.11] } \\
\text { Foraminifer- } \\
\text { bearing } \\
\text { nannofossil } \\
\text { ooze }\end{array}$ & $\begin{array}{l}\text { 586A-24-5, 1-2 } \\
\text { [262.51] } \\
\text { Foraminifer- } \\
\text { bearing } \\
\text { nannofossil } \\
\text { ooze }\end{array}$ & $\begin{array}{c}\text { 586A-28-2, 1-2 } \\
\text { [287.41] } \\
\text { Foraminifer- } \\
\text { bearing } \\
\text { nannofossil } \\
\text { firm ooze } \\
\text { and chalk }\end{array}$ & $\begin{array}{l}\text { 586A-30-3, 1-2 } \\
\text { [298.31] } \\
\text { Foraminifer- } \\
\text { bearing } \\
\text { nannofossil } \\
\text { stiff ooze } \\
\text { and chalk }\end{array}$ \\
\hline $\mathrm{C}_{\text {org }}$ (\% dry sediment weight) & 0.10 & 0.15 & 0.05 & 0.07 & 0.06 & 0.06 & 0.14 & 0.17 & 0.04 \\
\hline \multicolumn{10}{|l|}{ Hydrocarbon (ng/g dry sediment weight) } \\
\hline Ethene & 1.8 & 1.6 & 4.5 & 7.1 & 1.6 & 1.6 & 5.2 & 1.6 & 2.5 \\
\hline Ethane & 1.8 & 0.94 & 3.0 & 1.5 & 3.3 & 2.1 & 3.6 & 1.9 & 1.00 \\
\hline Propene & 3.1 & 0.96 & 2.7 & 3.7 & 2.1 & 1.8 & 3.4 & 2.0 & 3.4 \\
\hline Propane & 4.7 & 3.2 & 8.5 & 2.7 & 8.1 & 6.3 & 9.5 & 6.1 & 1.8 \\
\hline Methylpropane & 4.2 & 1.9 & 4.5 & 2.7 & 3.1 & 5.6 & 5.3 & 3.7 & 1.6 \\
\hline Methylpropene + 1-butene & 5.6 & 2.1 & 5.0 & 7.8 & 3.9 & 4.4 & 6.8 & 3.8 & 5.6 \\
\hline$n$-Butane & 3.5 & 1.9 & 4.5 & 2.3 & 73.9 & 5.3 & 6.3 & 3.9 & 1.4 \\
\hline trans-2-butene & 1.1 & 0.43 & 1.1 & 0.95 & 0.88 & 0.96 & 1.5 & 0.77 & 0.74 \\
\hline 2,2-Dimethylpropane & 0.04 & $<0.01$ & 0.06 & 0.01 & $<0.01$ & 0.09 & 0.12 & 0.04 & $<0.01$ \\
\hline cis-2-butene & 1.2 & 0.39 & 1.2 & 0.73 & 0.67 & 1.1 & 1.6 & 0.01 & 0.87 \\
\hline Methylbutane & 2.4 & 1.1 & 2.1 & 1.2 & 1.8 & 2.3 & 3.3 & 2.7 & 0.67 \\
\hline$n$-Pentane & 1.5 & 0.90 & 1.9 & 1.3 & 5.6 & 3.3 & 3.8 & 1.8 & 2.5 \\
\hline 2,2-Dimethylbutane & - & - & - & - & - & - & 5.6 & 7.5 & - \\
\hline Cyclopentane & $<0.1$ & - & 0.10 & $<0.1$ & - & 0.11 & - & - & - \\
\hline 2,3-Dimethylbutane & - & - & - & - & - & $<0.1$ & $<0.1$ & - & - \\
\hline 2-Methylpentane & 0.29 & 0.19 & 0.42 & $<0.1$ & 0.28 & 0.54 & 0.70 & 0.62 & 0.14 \\
\hline 3-Methylpentane & 0.77 & 0.34 & $<0.1$ & 2.2 & 2.4 & 0.94 & 1.0 & 0.60 & 2.1 \\
\hline$n$-Hexane & 3.4 & 1.4 & 2.3 & 3.3 & 2.0 & 3.2 & 4.0 & 2.5 & 1.8 \\
\hline Methylcyclopentane + 2,2-dimethylpentane & $<0.1$ & $<0.1$ & $<0.1$ & - & $<0.1$ & 0.12 & $<0.1$ & 1.4 & $<0.1$ \\
\hline 2,4-Dimethylpentane & $<0.1$ & $<0.1$ & $<0.1$ & - & $<0.1$ & $<0.1$ & $<0.1$ & $<0.1$ & $<0.1$ \\
\hline Benzene & 1.4 & 1.2 & 2.5 & 0.22 & 1.8 & 2.7 & 2.8 & 2.1 & 1.4 \\
\hline Cyclohexane & $<0.1$ & - & - & - & - & - & $<0.1$ & 0.74 & $<0.1$ \\
\hline 2-Methylhexane & 0.49 & 0.41 & 0.96 & - & $<0.1$ & $<0.1$ & - & 0.80 & - \\
\hline 2,3-Dimethylpentane + 1,1-dimethylcyclopentane & 0.26 & $<0.1$ & 0.48 & $<0.1$ & $<0.1$ & 0.15 & $<0.1$ & 0.43 & $<0.1$ \\
\hline 3-Methylhexane & 0.48 & 0.44 & 1.1 & - & $<0.1$ & 0.19 & $<0.1$ & 1.1 & $<0.1$ \\
\hline 1,cis-3-dimethylcyclopentane & $<0.1$ & 0.29 & 0.12 & $<0.1$ & 0.13 & 0.25 & 0.49 & $<0.1$ & 2.0 \\
\hline 1, trans-3-dimethylcyclopentane & - & - & $<0.1$ & $<0.1$ & $<0.1$ & - & - & $<0.1$ & - \\
\hline 1,trans-2-dimethylcyclopentane & - & $<0.1$ & - & - & $<0.1$ & - & $<0.1$ & 0.62 & - \\
\hline$n$-Heptane & 2.8 & 1.2 & 2.3 & 2.2 & 0.16 & 3.6 & 3.6 & 4.8 & 1.1 \\
\hline 1,cis-2-dimethylcyclopentane & - & - & - & -2 & - & - & - & $<0.1$ & - \\
\hline Methylcyclohexane & $<0.1$ & - & - & - & - & - & - & 6.8 & - \\
\hline 2,5-Dimethylhexane & - & - & - & - & - & - & - & 0.17 & - \\
\hline Ethylcyclopentane & - & - & - & - & - & - & - & 0.82 & - \\
\hline 1, trans-2,cis-4-trimethylcyclopentane & $<0.1$ & - & - & $<0.1$ & - & - & - & 0.53 & - \\
\hline 1,trans-2,cis-3-trimethylcyclopentane & - & - & - & - & $<0.1$ & - & - & $<0.1$ & $<0.1$ \\
\hline Toluene & 15.5 & 15.3 & 24.6 & 10.6 & 15.2 & 16.4 & 24.3 & 22.7 & 4.9 \\
\hline 2-Methylpentane & - & - & - & - & - & - & - & - & - \\
\hline$n$-Octane & - & - & - & - & - & - & - & - & - \\
\hline
\end{tabular}

Note: $-=$ concentration below or near detection limit. 